For copy-edited published version: "The Royal Road: Children, Play, and the Religious Life,” Pastoral Psychology 58, no. 5 (2009): 505-519.

\title{
The Royal Road: Children, Play, and the Religious Life
}

1

\begin{abstract}
This article explores the role of play in human development and religious faith. It begins with problems in children's play in contemporary society, as seen through history and sociology, and then analyzes the contributions of two psychologists, Erik H. Erikson and D. W. Winnicott, and recent thought on play in theology, childhood studies, and the scholarship of Donald Capps in particular. It argues that play has a potentially fruitful role in development and the life of faith for children and adults but modern constructions of play have obscured its place in adulthood and overlooked its uneven distribution among children in different classes and races.
\end{abstract}

Keywords Children, Play, Art, Development, Donald Capps, Erikson, Winnicott

\footnotetext{
${ }^{1}$ B. J. Miller-McLemore (contact)

E. Rhodes and Leona B. Carpenter Professor of Pastoral Theology

Vanderbilt University Divinity School

Nashville, Tennessee 37240

E-mail: bonnie.miller-mclemore@vanderbilt.edu
}

Telephone: 615-322-2776 
What is the nature of children's play in the United States and what role does it have in human development? Equally important, what role does play have in Christian faith and what might adults learn from children about the practice and capacity of play? These questions arise out of prior research on children, play, and work in which I identify play as a spiritual practice in families (2006) and work as an overlooked part of a child's Christian vocation (2008b; 2008c). I actually backed into the study of play when a good friend suggested I consider it as one place where my family practices faith in daily life. Yet articulating how play is an everyday spiritual practice was not easy. I entered into research on the topic of work with greater clarity, convinced that common expectations about children's participation in housework are too low. I discovered, however, that refashioning children’s chores requires reconsideration of play.

It is this conference, however, and the playful tenor of Donald Capps’s scholarship that confirmed the need for more research on the subject. Capps is a model of the playful practitioner of the art of pastoral theology. I can think of senior peers, such as Jim Dittes (1999) and Herbert Anderson (2001), and colleagues, such as Robert Dykstra (2001) and Brita Gill-Austern (1995), who attract me to their friendship and writing through playfulness with topics like ascetic therapy, Dr. Seuss, empathic preaching, and Sufi stories. Capps has done the same, if not more consistently. His publications cover a range of play-related topics, such as humor, art, poetry, wise fools, and rebellion (which I will later argue is play running amuck). I suspect that something about my own willingness to go out on a limb and playfully chase my research passions was part of his inclination to include me so generously in the conference celebrating his work. He has nurtured an important legacy through his work that engages psychology and the human 
psyche and positions the understanding of the self as a crucial dimension of the academic discipline of theology deserving of study in its own right (see Capps and Fenn, 1992). I am grateful to be among the beneficiaries.

In the end, however, I picked the subject of play not only because it seemed fitting but also because it sounded like more fun. My paper begins with some problems with children's play in contemporary society gleaned partly from history and sociology and then turns to fresh understandings in psychology and theology. I want to know what adults can learn from children and from these disciplines about play and faith. In honor of Don Capps, I focus on play in a few favorites in psychology, life cycle theorist Erik H. Erikson and object relations analyst D. W. Winnicott, supplemented by a brief foray into theology, with specific focus on Capps’s own work.

Although play is a term Winnicott and Erikson promote as essential to development and useful in understanding children, it is not easy to define (it consumes lines in dictionaries) and it has complicated connections to work and religion. Good work involves some level of play and good play sometimes produces constructive results, even if not by definition or intention. Some forms of play, like playing the piano or rock climbing, actually take lots of work. At the same time, play has unique qualities that labor often lacks, such as spontaneity, creativity, joy, freedom, and grace. In fact, as I have argued elsewhere, play involves a way of living as much as a specific activity, and any playful act becomes work if its joy dissipates (Miller-McLemore, 2006, p. 141). ${ }^{2}$ Play

\footnotetext{
${ }^{2}$ This complex interconnection between work and play makes it hard to actually characterize someone like Donald Capps as an exemplar of play. He is an incredibly hard
} 
also has a complicated relationship with religious practice and worship. Like good liturgy, it has the potential to suspend time, transform space, and recreate reality without superseding it. Both play and worship move us into a liminal place where we face failure, loss, finitude, and destruction without serious risk or, inversely, where we experience triumph, metamorphosis, and regeneration. Play resembles what Catholic theologian Richard Gaillardetz (2000), following social philosopher Albert Borgmann (1984), calls a “focal practice” that brings us into intimate interaction with nature, other people, our bodies, and a shared rhythm of life open to God's presence. Recently I heard a hotel chain exploit the resemblance between play and prayer by co-opting and rewording a common religious saying in advertising, “families who play together, stay together.” In many ways, play is a powerful source of renewal and connection akin to religious practice. And smart marketers at least recognize (and know how to exploit) its quasireligious power.

In tracing ideas about this complex part of life through psychology and theology, the hunches with which I began developed into two full-fledged, complementary arguments. On the one hand, most treatments of religious faith underestimate children's insight into play and its relevance for adults. Play has a potentially fruitful role in the life of faith and yet it is often suspect and neglected in theological studies. At the same time, many psychological and spiritual portraits of play mistake it as an unmitigated good and ignore social, political, and economic injustices that constrict it. Erikson and Winnicott are pivotal and ambiguous figures because they recognize the value of play and

worker. Did he really know how to play? Or did the way he worked embody play? Is play as much attitude as activity? Or is some fuller embodiment of play necessary? 
contribute to its romanticization among children. In short, I will argue that there is spiritual wisdom in play but that modern constructions have also romanticized, idealized, and infantilized it. My paper starts with the problems and moves toward the potential.

\section{Problems with children's play}

As a white, middle-class mother of three boys now in their late teens and early twenties, I confess: I am no stellar example of playfulness. A classic high demand person with a job and three kids, I often forget to play. That my work — reading and writing —is also a pastime and pleasure makes it hard to recognize when this vocational merger of play and work can turn dour and lose its levity and grace. I am most troubled in this article, however, with culpability on a third front: I have watched and participated in what I see as an unfortunate modern polarization between working adults and playing children.

Many factors perpetuate this bifurcation. Although it may seem odd to begin an analysis of play with work, I start with the decline in domestic chores among middleclass children because this decline says a great deal about how many people in contemporary U.S. society understand play. Until quite recently scholars rarely included children in time use studies of the division of domestic labor. One 1994 analysis, Men, Women, and Household Work, is typical (Goodnow and Bowes). Children only appear in the book in terms of the impact of childhood experience on adult domestic arrangements and as extra work for adults in discussions of childcare, never as workers themselves.

When researchers do include children in such studies, they often find that most children spend little time on chores, a pattern that sometimes mimics paternal behavior, especially for boys. A study in the early 1980s involving interviews with 764 children in 
five neighborhoods of Oakland, California, by an interdisciplinary team of social scientists concludes that the "most frequently performed chores took relatively little time," “required little creativity or initiative," and "were not central to the organization of the household." Children are more often "products, not producers, of domestic work" and “rarely regarded as bona fide workers” themselves (Medrich, et al., 1982, pp. 133, 140, 144). Another study around the same time by a pair of sociologists confirms that children "probably represent more, rather than less, work for the parent." Chores spark conflict between parents and kids, similar to the tension between husbands and wives over housework (White and David B. Brinkerhoff, 1981, p. 792; see also Sterns, 2003, pp. 156-57). Consequently, parents are "uncertain as to the significance of these activities" (Medrich, et al., pp. 149, 157). Many assign chores because they are considered good for children, not because material or financial support is needed or because chores are a duty or good in themselves. Many give up on chores because it is simply easier to do the work oneself. Whereas prior to the twentieth century most families assumed children should contribute to the essential labor of the household, today this is less the case. As I have observed before, when I asked one of my pre-teen kids to do some chore several years ago, he protested, "You're the adult. You're supposed to do that” (2003, p. 4).

There are, of course, practical reasons for this change. New labor saving devices like plumbing and electricity eliminate tasks previously assigned children, while standards for other jobs, like lawn or car care, have risen. The move away from farms and rural settings, distance between home and workplace, and children's preoccupation with school and other activities also allow fewer opportunities for what a Canadian sociologist 
calls the natural "learning-to-work sequence” in which young children begin to imitate the work of parents and older siblings (Stephens, 1979, pp. 37, 77).

A major change in the last century, however, occurred alongside these practical changes: a new cultural view of children and play. Although material history reveals the presence of toys and the value of play throughout civilization, in modernity children's play acquired a privileged place, disconnected from adulthood and sometimes highly organized by adults. By and large, as historian Steven Mintz observes, a "useful childhood" where children help sustain families gave way at the turn of the twentieth century to a "sheltered childhood, free from labor and devoted to play and education" (2004, p. viii). In other words, the underestimation of children's capacities for domestic work corresponds with an overestimation of their need for play.

Modern psychologists occupied a key role in this cultural transformation. Today, some admit they have contributed to a rampant "play ethos" or unexamined idealization of play as crucial for children’s development (Smith, 1995). Although psychology has yielded rich insight into children and play to which I will return, it also fed the modern assumption that children need extended hours of uninterrupted play for healthy development. The modern guru of the "hurried” child, psychologist David Elkind, is a good example. When he insists in the second edition of his widely read book that today's children "work much more than they play and this is the reason that they are so stressed," few people question this claim (1989, p. 198). Parents, schools, and the media, he says, have all robbed children of a natural time of what he christens “pure play” (p. 199). Play is the "antidote to hurrying” (p. 195). 
In one way, Elkind is right. Some kids are pushed too fast and their play is overly structured by adults. But he has a select middle-class population in mind and his social and political analysis just does not go deep enough. He fails to see that adults are caught in the same postmodern challenges of time pressure and overextension that many children face. Consequently he perpetuates a romanticized portrait of children's play that overlooks important historical and social realities. A long, carefree, idyllic childhood is largely a post-World War II invention that has never applied equally to all children. Many middle-class children today do not work nearly as much as their peers in other historical periods and in less privileged contexts today. As Mintz notes in his history of childhood, Huck's Raft, before author of Adventures of Huckleberry Finn Samuel Clemens left home at age seventeen in the mid-nineteenth century, he had "worked as a printer's apprentice; clerked in a grocery store, a bookshop, and a drug store; tried his hand at blacksmithing; and delivered newspapers” (2004, p. 2). Other less renowned "laboring children" of the nineteenth-century pulled weeds and protected crops on family farms at age five, separated coal from slate and rocks in mines at age nine, worked in textile mills at age eleven, taught in frontier schoolhouses at age fifteen, braided leaves into hats in home industries, and drove wagons across the Western prairie. Indeed, the “frontier could not have been settled,” Mintz argues, “without children’s labor” (p. 150).

This is not to argue that child labor is desirable. It is simply to observe that public outcry over hurried children is aimed more at middle-class adults anxious about their children than at those who really do lack the means to play because of poverty and difficult circumstances. Not only have children of less privileged classes and nationalities, especially children in developing countries, not lived by this modern 
construction of childhood as a protected time of playful innocence. At times, they have indirectly suffered the consequences of those who try to uphold it. It might even be argued that the protected, safe, and unproductive play of middle-class children has been largely subsidized by the hard work of less fortunate children and their parents in the United States and around the world. Even though public parks and playgrounds originally emerged as an attempt to get working class and immigrant children off the streets (Zelizer, 1994, pp. 34-35), the modern ideal of free play has been hard to extend to children without resources. The heightened pace of middle-class children’s extracurricular activities stands in contrast with the bleaker opportunities for children living in impoverished contexts. Instead these children often suffer from the adult responsibilities they bear in securing the family's survival.

The twentieth-century middle-class, however, began to associate childhood more and more with enjoyment, and, as historian Peter Stearns argues, adults increasingly saw themselves as “responsible for providing it” (2003, p. 163). The parental obligation to entertain children through toys, elaborate birthday parties, and Disney trips “intensified fairly steadily in the $20^{\text {th }}$ century” (p. 191). This responsibility often fell more heavily on mothers than fathers. As scholar of American studies Nancy Pottishman Weiss remarks, the "shearing of moral obligations from the child's role accompanies an expansion of maternal moral responsibility” (1985, p. 292). Another time use study of 1300 white, two-parent families in 1976 revealed that while mothers on average put in fifty hours of housework a week, children between six and eleven spent three and a half hours (Walker and Woods, p. 38, cited by Zelizer, 1994, p. 3). In the 1960s, psychologists who studied working mothers and child-rearing practices actually interpreted the parental request that 
children work as a "sign of rejection" or as a "burden that inhibits" children's achievement in school or social life (Roy, 1961; McClelland, 1961, cited by White and Brinkerhoff, 1981, p. 789).

Today many mothers and fathers put in lots of hours to sustain their children’s play on field, court, and stage. But there is a gap between what kids and adults consider fun, according to a recent study on organized recreational sports (Singer, 2004, p. 210). When the researcher asked fourth through eighth grade players why they played, none identified goals claimed by coaches and parents, such as improvement, performance, selfdiscipline, competition, and winning. They all said they played for fun. Most enjoyed playing more when coaches and adults left them alone. Kids, the report concludes, have "numerous concerns and interests that go beyond what adults have in mind for them" (p. 223). But adult perceptions of children and play as well as adult anxieties about children have provided an excuse for intervention, surveillance, and control (Ennew, 1994, p. 140; Rodgers, 1985, p. 131).

I confess again that with each turn in this account of the split between working adults and playing children, I am guilty. Eager parents and psychologists, however, are not the only ones to blame. Technology and big business have helped turn play into a commodity, something that can be bought, sold, and otherwise used for some other end beyond its own value. The market has a way of simultaneously invigorating play, from athletic sports to fantasy fiction, and taking it over until it becomes difficult to experience what Gaillardetz identifies as the "grace and blessings that come to us" through play, (2000, p. 11). Today's market and the Internet can turn even the most innocent of child play—bubble gum blowing, for example—into a national contest. 


\section{Understanding children's play and its potential}

Neither Erikson nor Winnicott anticipated the exaggerated view of children’s

developmental need for pure play to which they contributed. They would have argued against this. Or so I would like to think.

Both Erikson and Winnicott were born near the turn of the twentieth-century and participated in the growth of the psychoanalytic movement at mid-century. But oceans, schools of thought, and religious background separated them. Erikson studied in Vienna with Anna Freud and immigrated to the United States in 1933, associated largely with ego psychology, and sustained only vague connections to his Jewish heritage. Winnicott worked closer to Anna’s arch rival Melanie Klein in Britain, contributed significantly to the development of object relations theory, and was shaped by a Methodist and Anglican context. No wonder few people have linked these two psychologists in order to challenge modern misconceptions of children and play.

Erikson and Winnicott share an abiding interest in play and children, however. Both liked working with children. Both experimented with play in clinical analysis, using and even joining children in play. Both noticed the absence of any significant theorizing about play, even by Anna Freud and Klein who had begun to use it with children. ${ }^{3}$ Their respective understandings build on Freud and Klein's view of play as a child's means of

\footnotetext{
${ }^{3}$ There is something about play "that has not found a place in the psychoanalytic literature,” Winnicott says (1971, p. 41). Instead of linking it with masturbation and sexual stimulation, it deserves "to be studied as a subject on its own” (p. 39).
} 
communication (See Freud, 1928; Klein, 1949). ${ }^{4}$ Together they suggest a more satisfying understanding than Elkind's reduction of play to an antidote to hurrying.

Play offers what one biographer calls the “conceptual elasticity” by which both Erikson and Winnicott diverged from Sigmund Freud and emerging psychoanalytic orthodoxies (Friedman, 201). Where Freud saw dreams as the "royal road" to the human psyche, Erikson saw play (1950; 1963, p. 209). Where Freud dug deep into the interior dynamics of the hidden unconscious, Winnicott leaped into transitional space between mother and child and claimed, "In playing, and perhaps only in playing, the child or adult is free to be creative” (1971, pp. 53-54). Freud associated children with the primitive and irrational and saw the triumph of the id in child play and the defensive sublimation of instincts in adult play, closely linked to catharsis and masturbation. By contrast, Erikson and Winnicott credited children with a particular kind of wisdom and saw in their play a capacity of the ego or the self to create a new world of hope that adults might emulate. They believed children used play emotionally and socially to act out "much more than they could possibly say or probably know 'in that many words,'” according to Erikson (1977, p. 30). Play is a form of self-expression for Erikson and a transitional activity essential for creativity and health for Winnicott.

Other people name identity and generativity as linchpins of Erikson’s theory. Play deserves greater recognition. When he names the social rituals that accompany each stage in his essay on the "Ontogeny of Ritualization” (1966), it is the many forms of play, not identity or generativity, that connect and orient the stages. It is through play that the first

\footnotetext{
${ }^{4}$ A fuller non-sexist or feminist investigation needs to retrieve and analyze this early tradition.
} 
and last rituals of life "circle” back "into each other" in the words of Erikson’s biographer Lawrence Friedman (1999, p. 404). Erikson refers frequently to William Blake's poetic notion that “the child's play and the old man's reasons are the fruits of two seasons.” For him, this passage suggests that play anchors both ends of the life cycle (1963, p. 222; 1977, p. 3). As Capps notes, the schema itself is a "product of creative play" analogous to a musical score. It "invites us to 'play' with it” and its syntonic and dystonic melodies (2004, p. 11).

Play also anchored Erikson's life. He was an artist at heart, even if his youthful forays into the European art world led to mixed results. ${ }^{5}$ The artistic community of his mother provided what he describes as his "first male imprinting" (1970, p. 742). When he entered the emerging Viennese school of psychoanalysis as a young adult in the late 1920s, he worried that those with a scientific approach might not tolerate his artistic bent or his gifts for relating to children. He managed partly by projecting artistic interests onto Freud who had in fact amassed a collection of antique statues by this time and was busy analyzing art and literature. Nonetheless, early on Erikson tells Anna that, no matter how much he learns about himself, psychoanalysis is not the profession for him (Coles, 1970, p. 22). He still wanted to draw and paint. Later he says he would never "have made it" in the rational world of psychoanalysis without depending on the visual orientation of art (cited by Friedman, 1999, p. 71). As he declares in 1950 in the foreword to the first edition of his signature publication, Childhood and Society, "I came to psychology from art, which may explain, if not justify, the fact that at times the reader will find me

\footnotetext{
${ }^{5}$ He recognizes his self-depiction as an artist as a "European euphemism for a young man with some talent, but nowhere to go" (1964, p. 20).
} 
painting contexts and backgrounds” rather than pointing to "facts and concepts” (1963, p. 18). He describes his approach as “configurational,” based as much on visual image as on words. He was open to entering the emerging area of child analysis because he knew that “as an artist, I felt close to children.” His “basic apprenticeship was watching children at play” (cited by Evans, 1967, p. 86).

Of course, art and children at play are not exactly the same. There are, however, rich connections between the three. Winnicott understood this better than Erikson. In his theory, playing begins in infancy but is not left behind in childhood. It extends specifically to therapy and more generally to what he describes as the "ultimate stages of a human being’s capacity for cultural experience” (p. 40). Although he does not say here what he includes in the later stages, he is drawing a continuum from child play to art and other forms of adult play. He was interested in play throughout his entire career and created and used games diagnostically and therapeutically, most famously the squiggle game $(1958,1971)$ and, before that, the spatula game (1951). This interest receives its best theoretical articulation in Playing and Reality, published in 1971 shortly before his death. This book develops core ideas first put forward in 1953 in his initial thoughts on transitional objects. This conceptual breakthrough rests on assumptions about the capacity to play. He portrays the earliest interaction between baby and mother as a “playground.” Transitional objects are play objects. A child’s use of a teddy bear or blanket is its first achievement and its first experience of play (p. 47). The child uses the object to create an intermediary space of illusion that interweaves the subjective and objective reality of love and support and allows the child to move away from and back toward the mother. 
Like Erikson, Winnicott also finds inspiration from a poet, Bengali Rabindranath Tagore, and his words, "on the seashore of endless worlds, children meet.” The line nagged at Winnicott for a long time. As a good Freudian, he first thought the meeting of sea and shore referred to male-female sexual intercourse and the child's emergence, and then he equated them with the mother's body and the baby's merger with her. Finally, he realized its allusion to play's transitional place on the boundaries of worlds or, in his own rewording, "on the seashore of endless worlds, children play" (1971, p. 95). His whole theory, one might say, gets played out within the space of this one line, just as Erikson found the line from Blake on child's play and old man's reasons encapsulating his own.

For Erikson, Montessori training and lifelong marriage with Canadian Joan Serson offered means for retaining his basic orientation toward art and play. One of few men credentialed in 1932 with a Montessori diploma (earned mostly by women at the time), this education focused on objects made and arranged by children and offered a "counterpoint to psychoanalytic preoccupation with inner emotional life, verbally articulated" (Friedman, 1999, p. 68). In his teaching and later his therapeutic work with children, he saw that there was as much to be learned through careful observation of nonverbal enactment as through verbal analysis. In Boston in the mid-1930s he even used blocks and toys with college students. Initially followers of Anna Freud felt ambivalent about Erikson's exploration of play as a therapeutic tool because it resembled too closely Klein's use of play in discovering children's feelings and thoughts. His approach was also unsettling because he proposed a kind of egalitarianism between child and adult instead of the commonly accepted hierarchical view of traditional psychoanalysis. Only 
by giving children the same kind of respect and trust given adults would adults understand them (Friedman, 1999, pp. 92-93).

Joan stood behind Erikson’s penchant for play and art. When Capps corresponded with her several months after Erik's death in 1994, she shores up the centrality of his earliest vocation: "It is important to stress—always—-that he was an artist," she says (cited by Capps, 1996, p. 93). In the early years of their relationship, she found the orientation of psychoanalysis toward inner life and verbal interpretation to be stilted. She was a dancer and had come to Vienna to pursue a dissertation begun at Columbia Teachers College on the teaching of modern dance, a project she gave up for family and Erik’s advancement. Keeping play alive was one way she managed his life and sustained her own interests, whether through encouraging his move away from traditional analysis, urging him to play the piano, teaching him to waltz, or weaving the stage theory into a vast array of colorful tapestries. Her fascination with the arts continued throughout her life. Erik dedicated one of his later books, Toys and Reasons, to her "because of her lifelong devotion to the grace that is play” (1977, p. 13).

In some respects, the dedication is an understatement. Left behind to tend home and three children while Erik moved and traveled, her influence over his thought and even his transition from German to English is significant. When Joan tells her version of the development of the life cycle theory as "Erik and I have understood and presented it," she gives herself a prominent role (p. 1). ${ }^{6}$ In her preface to the extended version of The

\footnotetext{
${ }^{6}$ When they discover that their original theory omitted the very stage in which they both found themselves immersed — parenting and productivity — it is largely her own insight
} 
Life Cycle Completed, republished in 1998 four years after Erikson's death, she says she and Erik laughed together at the "fascinating paradox!" that the "great Shakespeare" had himself failed to include play in his own poetic rendition of the "seven ages of man." “Perhaps it was blindness,” Joan remarks, "to the role of play in the lives of every child and adult” (p. 2).

So what did Erikson and Winnicott contribute to the problematic split between child play and adult work of today? They gave child play preeminence. Play has an acute phase of ascendancy and development, whether in the very first moves toward selfhood in infancy or in the "toy stage" or "play age” in the third stage of development prior to the "school age” and its imposition of “defined work roles” (1982, p. 77). Erikson draws the line between play and school sharply, perhaps too sharply. Moreover, in his earliest formulation of the play stage as a conflict between initiative and guilt Erikson does not move far from Freud's oedipal stage and some of its stereotypes. Erikson describes initiative as "being on the make” for a "favored position with the mother," connects this with guilt, and suggests a girl's anatomy shapes her play toward "catching” or "making oneself attractive and endearing” (1963, pp. 255-256).

Despite these problems, both Erikson and Winnicott suggest that children have unique play needs. In Erikson’s words, play offers a “temporary victory over . . . gangling body and self” and a "protected space” or a smaller and more "manageable world” to test out social roles (1963, pp. 211, 221). Children need this “intermediate reality between phantasy and actuality” (p. 212) to dramatize and master problems, a claim in Erikson in her account. "In a shocking moment of clarity I saw what was wrong”: the stage of generativity and stagnation was completely missing (1998, p. 3). 
that foreshadows Winnicott. Because play occurs in the “intermediate area” between objective and subjective reality or between "primary creativity and objective perception based on reality-testing" (1971, p. 11), it is "precarious" and even a bit "frightening," Winnicott observes. Consequently, responsible adults need to be "available when children play,” but play excessively organized by adults is a problem because it implies that the "child or the children are unable to play in the creative sense" of the word (p. 50).

At the same time, both extend ideas about play into adulthood. Whereas children use play to move forward in development, adults use it to re-create or to step temporarily outside the demands of work. Children "play it out”; adults "talk it out.” So the "playing adult steps sideward into another reality,” in Erikson’s view, while the "playing child advances forward to new stages of mastery” (pp. 213, 222). There is a certain regressive aspect to adult play, in fact, although not in a flat defensive Freudian sense. Following psychoanalyst Ernst Kris, adult play is regression in the service of the ego or progression forward, “most evident when an artist makes a cultural product” (Friedman, 1999, p. 94). Winnicott talks less about regression and more about extension. So the intermediate area of transitional play is extended into adulthood through the "intense experiencing that belongs to the arts and to religion and to imaginative living, and to creative scientific work” (1971, p. 14).

In a word, even though they drew distinctions between child and adult play, neither intended differences in play between children and adults to evolve into polarization or division. The very principles of epigenetic development suggest that nothing is confined to a single stage. Ego strengths have acute phases, but each item, such as play, exists in some form before its critical time and continues to take distinctive forms 
as growth continues. When Erikson refers to child's play and old man's reasons as the “fruits of two seasons," he assumed that Blake meant to recognize the integrity of a child’s play and the "latent infantility in mature reason” (cited by Friedman, 1999, p. 201). ${ }^{7}$ Child's play and the products of the artist simply represent the "most fascinating extremes of 'play"” (Homburger, 1937). The "lifelong power of human playfulness in all the arts” and the human "ability to laugh” are "grounded” in children’s play (1982, p. 77).

Similarly, Winnicott enumerates features of play that emerge in infancy but characterize health at every age: spontaneity, concentration, precarious balance between fantasy and reality, creativity, embodiment, trust. Winnicott goes so far as to say “whatever I say about children playing really applies to adults as well” (1971, p. 40). Psychotherapy as a means to health is nothing more or less than an attempt to cultivate play where play has turned sour. As he states, "Psychotherapy has to do with two people playing together." Simply stated, its goal is to bring "the patient from a state of not being able to play into a state of being able to play” (p. 38). Psychoanalysis is just a "highly specialized form of playing” (p. 41).

Provoked in part by field research, Erikson challenges the juxtaposition of child's work and play in the dominant culture. Among the Cheyennes, a child's “play” learning to fish or using a toy bow and arrow has a crucial social place alongside adult work. The Cheyennes treat it with immense seriousness. The "contrast with our society is very great,” Erikson says. We relegate children’s play to the sidelines and do not see it as an opportunity to participate fully as a "small partner in a big world” (1963, p. 238).

\footnotetext{
${ }^{7}$ As Friedman says, the “child's successful play became the adult's efficacious reason; both reduced data 'to the size and an order in which they seem manageable’” (p. 201).
} 
In other words, there is biological and psychological grounding for a moral and spiritual claim that shapes both Erikson and Winnicott's psychology: adults need play as much as children, even if in more complicated forms. Even though play is a child's distinct language or experience, it is not an "intermission” from life or something left behind. Play demonstrates the "capacity of the ego to find recreation and self-cure,” says Erikson (1963, p. 209). Health is, according to Winnicott, a "state of being able to play" and illness "not being able to play” (1971, p. 38). "Playing is itself a therapy” (p. 50). In short, Erikson and Winnicott give play an essential place in childhood at the same time as they recognize its value for people of all ages.

\section{Play, pastoral care, and the religious life}

Despite its contributions to health, play has not figured prominently in theological anthropology, especially among those shaped by a Puritan and Calvinist work ethic. The subject of work has certainly received attention, as a spiritual discipline in monastic circles, for example, or as a vocational call in Protestant realms. But there is something frivolous and even dangerous about play that has made it harder to justify as an essential part of the Christian life. Moreover, theologians and most practicing Christians seem to agree with modern premises that the mature adult is the proper subject of theological inquiry and that play is a child's activity.

But psychoanalysts like Erikson and Winnicott show why play deserves a more central place, at least psychologically. ${ }^{8}$ Thanks in part to their influence, its importance

\footnotetext{
${ }^{8}$ Heinz Kohut (1980) might also be included here for considering humor essential to mature development.
} 
has resurfaced in pastoral theology among those most influenced by them, such as Donald Capps, and more recently among other scholars interested in children and religion. Investigation of their work, although limited by restrictions of time and space in this article, provides at least an initial means toward reconstructing play's potential contributions to development and religious practice.

I do not think it farfetched to say that play anchors Capp’s life as it does Erikson's. ${ }^{9}$ In a recent book on the spiritual struggles and triumphs of early adolescents as losers, loners, and rebels, he chooses the rebel as the character type with which he most readily identifies (Dykstra, Cole, and Capps, 2007). Rebellion tests the boundaries of good behavior and can have destructive consequences. But Capps sees in its benign forms the capacity to play.

Capps explores humor in a number of venues $(2002,2005,2006)$, but in his reflection on adolescent spirituality humor appears as a form of moderate or tamed rebellion. Healthy spiritual rebellion in boys and adults involves the capacity to play a joke, laugh at ourselves, and gain greater perspective on the follies, foibles, and traps into which adults and religion so commonly fall. As I read his description of humor and rebellion, I could not help but notice that boys use humor against “cruel, unfair, or illtempered adults” in much the same way that prophets and reformers used public outcry against idolatry and injustice in the Jewish and Christian traditions (Dykstra, Cole, and

\footnotetext{
${ }^{9}$ It is important to note that I do not see play as serving a singular psychological function or restorative role, whereas Don sees humor and play primarily as compensating for maternal absence and melancholia (2007a; 2007b). This places significant responsibility on mothers. I see play as having a more expansive purpose.
} 
Capps, p. 161). Non-malicious rebellion, just like play, subtly subverts oppressive authority and sets the player, the joker, and the laughing free. In his words, humor allows us to "stand over” conventional religion and call its "convictions and assumptions into question” (p. 139). As Freud himself said, humor falls somewhere between revolution and resignation. It resists social forms without destroying them entirely. So rebellion is, in a way, play running a bit wild.

Slightly earlier in his career, Capps also explored the playful potential of poetry (1993) and parables (1981, 1984, 1990). Although rebellion, jokes, poems, and parables cannot be flatly equated with play, they share characteristics that Capps identifies in his study of poetry. Parables and poetry pack a punch. They open up to the "unexpected and unanticipated,” the “surprising” (p. 1). They are “necessarily open-ended,” speak concretely about human experience, “challenge our usual routine,” and help us look at life in anew (pp. 2-3).

Play colors not only the content of Capps’s work. It also characterizes his method. Play is most evident in Capps’s affinity toward psychology as an "eccentric” adventure into the psyche (1999, p. 331), his dance between the two arenas of psychology of religion (e.g., 1977) and pastoral care (e.g., 1990), and his willingness to break rank with academic convention and make radical claims (e.g., about Jesus [2000] or masturbation and homosexuality [2003]). He also uses poetry and art to understand pastoral theological method. Contrary to claims in cognitive developmental theory that our minds, morality, and faith evolve from concrete images to the realm of pure reason, art theory suggests that visual perception is not something left behind or developmentally inferior. Sensory 
attention to the particular and cognitive abstraction about the general are "simply two different approaches to reality” (1999, p. 329).

Just as certain kinds of knowing best understood by young children (e.g., imaginative, illusory, sensory knowledge) have a place throughout life, so also does “aesthetic judgment” have as valid a place in pastoral writing and practice as scientific, rational, or theoretical judgment (1996, p. 94). The "wise fool” first described by Alistair Campbell (1981) is favored by Capps as a metaphor for pastoral ministry. The "wise fool” in both biblical and contemporary contexts calls into question commonly recognized forms of truth and knowledge and looks for wisdom where least expected. The wise fool performs the "art of reframing" problems to see them in an entirely new way (1990, p. 169).

Play is a more active component of pastoral pedagogy and practice than many people realize. Most pastoral theologians use some form of role play in teaching. Some have written about this (Couture, 1999; Miller-McLemore, 2007, 2008a) and others have written about play and pastoral care (Lester, 1985; Miller-McLemore, 2006; Koppel, 2003, 2008; Hamman, 2007). But few have recognized its centrality and complexity as an aspect of childhood and adulthood. We need to know more about our intellectual turn to play and its potential benefits and dangers. A pastoral propensity to play surely gets us into trouble. It can lead us to misuse and distort the biblical and scholarly sources we depend on in our research. It tempts us to jump to outrageous conclusions. It can lure us toward sloppiness in theory and academic standards. No wonder those in other fields do not always take us seriously. We are often playing around. But if scholars in all fields were honest, they would admit that their scholarly research and teaching involves play as 
well, even if covert and less obvious. In fact, pretensions about rigor sometimes impede the ability to recognize the genuine creativity that arises largely through play. For, just as surely, play has the potential to connect people, deepen ideas, and invigorate life.

Pastoral theology finds encouragement from religion scholars in childhood studies who have also begun to explore the contributions of play in religious education, parenting, and social justice. Most obvious is the idiosyncratic ministry and writing of the founder of “godly play,” Jerome Berryman. Influenced by his own exposure to Montessori and psychology, Berryman has used a particular form of play-meditative, artistic, and dramatic play—in carefully structured ways over the last twenty years to revitalize children’s religious education and open up space for divine knowing in Christian contexts (1991). More recently, systematic theologian David Jensen (2005) and religion scholar Paula Cooey (1998) have suggested that play can also revitalize parenting and society.

In a concluding chapter of Christian Nurture, nineteenth-century religious educator and Protestant theologian Horace Bushnell (1908) offers something unique to theology, particularly in light of his Calvinist milieu, Jensen says: a reclamation of play as one of the joys of parenting. His advice to parents is simple: play with your kids. Religion and its “needless austerity” too readily suppress the “joyous gambol” with which life begins.

Not unlike Winnicott's view that the "whole cultural life” expands out of a child's first foray into play (1971, p. 102), so Bushnell also argues that play is the "forerunner of religion.” He does not confine play to the “fancies of childhood,” Jensen observes. Rather he extends "its laughter to all generations and facets of human existence" (2005, p. 56). 
Consequently, Christianity should be a "friend of play" and it should promote play as a mark of Christian maturity. In Bushnell’s words, “play is the symbol and interpreter of . . . Christian liberty. ... God has purposely set the beginning of the natural life in a mood that foreshadows the last and highest chapter of immortal character” (1908, pp. 339-41, cited by Jensen, 2005, p. 56). Play can foster what Bushnell describes as "Christian liberty” partly because it is subversive, as Jensen points out. In contrast to many other activities, play “is strangely resistant to structures of domination and control.” Even though capitalists are always looking for ways to make money on the human love of play and parents try to control children's play or use it to shape desired behaviors, children and adults consistently find ways to use play to shape meaning on their own terms.

As this suggests, play stands in a paradoxical relationship with power. On one hand, the rough-and-tumble play of kids and animals as well as competitive play, such as the Olympics or Superbowl, is about establishing social power, economic strength, physical prowess, and hierarchies of talent and authority. On the other hand, play allows children and adults to experiment with our basic powerlessness over life as a defining characteristic of existence. Jensen says, “To play with someone, by definition, is not to control, but to let be. What is really enjoyable about children's play is not the activity that one has structured, but the surprise” (p. 56). He also cites Catholic theologian Karl Rahner who argues that childhood is that "state which endows us with the power still to be able to play.” For Rahner, this “power still to be able to play” is actually the power to give up power- “ "to expect the unexpected, to commit ourselves to the incalculable ... , to recognize that the powers presiding over existence are greater than our own designs” (Rahner, 1971, p. 42, cited by Jensen, 2005, p. 128). 
Play’s benefits are not only for children or those with money and means. Adults owe all children a world in which, as Cooey puts it, “every child who wants might learn to dance” (1998). Cooey’s mother was an accomplished dancer who turned her energies to teaching dance to kids from lower middle class and working families in rural north Georgia and quietly subverted oppressive social structures in her own small way. Even when many kids could not pay the dollar per hour for dance and fifty cents for half-hour baton twirling lessons, she found a way to lure "even the most cynical,” the most hard up, and the clumsiest into skipping across the stage with pirouettes, twirls, and leaps. Dance became a metaphor for a joy-filled defiance of injustice. Later, Cooey states what she learned from her mother more formally in a book on the family: "Christians need to be at the forefront of advocating for the protection of all children, regardless of what kind of household, religious or otherwise, they come from” (1996, p. 101).

Christians actually use the term child to include biological children and all people as children of God. Play prepares children for adulthood. But since childhood is an aspect of mature Christian adulthood, play has relevance across the generations. Indeed, children often remind adults of what we have forgotten. The gift of children lies partly here: They invite adults to play. The modern construction of childhood as a time of unbridled play for some children has obscured the role of play in adulthood and the injustice of an uneven distribution of work and play among children in different classes and races. Play is a unique attribute of childhood. But to restrict it by age and class is wrong. If play is an important part of healthy childhood and an essential practice of faith, then it is best shared generously and justly across generations and among classes and races. 
Ultimately, play should not even be restricted in time or to humans alone. Bushnell has solid scriptural warrant when he connects play with paradise. In Psalm 104, the animal Leviathan cavorts and God takes ample pleasure in its play. In Proverbs 8, wisdom plays like a child creating the world, and in God's reign to come, as foretold by the prophets, the young child will frolic without fear over the snake’s home (Isaiah 11:8) and boys and girls will fill the streets with their games (Zechariah 8:5). So, thank goodness for scholars like Don Capps who boldly invite us to embrace the pastoral potential of humor, rebellion, jokes, poetry, and play.

\section{References}

Anderson, H. (2001). Sense and nonsense in the wisdom of Dr. Seuss. New theology review, 14/3, 37-50.

Berryman, J. W. (1991). Godly play: An imaginative approach to religious education. Minneapolis, MN: Augsburg.

Borgmann, A. (1984). Technology and the character of contemporary life. Chicago, IL: University of Chicago Press.

Bushnell, H. (1908). Christian nurture. New York, NY: Scribners.

Campbell, A. V. (1981). Rediscovering pastoral care. Philadelphia, PA: Westminster.

Capps, D. (1981). Biblical approaches to pastoral counseling. Louisville, KY: Westminster John Knox.

Capps, D. (1984). Pastoral care and hermeneutics. Philadelphia, PA: Fortress.

Capps, D. (1990). Reframing: A new method in pastoral care. Philadelphia, PA: Fortress. 
Capps, D. (1993). The poet's gift: Toward the renewal of pastoral care. Louisville, KY: Westminster John Knox.

Capps, D. (1996). Erikson’s 'inner space’: Where art and religion converge. Journal of religion and health, 35, 93-115.

Capps, D. (1997). Men, religion, and melancholia: James, Otto, Jung, Erikson. New Haven, CT: Yale University Press.

Capps, D. (1999). The lessons of art theory for pastoral theology. Pastoral psychology, 47, 321-346.

Capps, D. (2000). Jesus: A psychological biography. St. Louis, MO: Chalice.

Capps, D. (2002). Men and their religion: Honor, hope, and humor. Harrisburg, PA: Trinity Press International.

Capps, D. (2003). From masturbation to homosexuality: A case of displaced moral disapproval. Pastoral psychology, 51, 249-272.

Capps, D. (2004). The decades of life: Relocating Erikson’s stages. Pastoral psychology, 53, 3-32.

Capps, D. (2005). A Time to laugh: The religion of humor. London/New York: Continuum International.

Capps, D. (2006). Religion and humor: Estranged bedfellows. Pastoral Psychology, 54, 413-438.

Capps, D. (2007a). Mother, melancholia, and play in Erik H. Erikson’s Childhood and Society. Journal of Religion and Health, 46, 591-606.

Capps, D. (2007b). Mother, melancholia, and humor in Erik H. Erikson’s earliest writings. Journal of Religion and Health, 47, 515-532. 
Capps, D. and Fenn, R. K. (1992). Individualism reconsidered: Readings bearing on the endangered self in modern society. Princeton, NJ: Princeton Theological Seminary Monograph.

Coles, R. (1970). Erik H. Erikson: The growth of his work. Toronto: Little, Brown, and Co.

Cooey, P. (1996). Family, freedom, and faith: Building community. Louisville, KY: Westminster John Knox.

Cooey, P. (1998). That every child who wants might learn to dance. Cross Currents: The Journal of the Association for Religion and Intellectual Life, 48/ 2, 185-197.

Couture, P. D. (1999). Ritualized play: Using role play to teach pastoral care and counseling. Teaching Theology and Religion, 2/ 2, 96-102.

Dittes, J. E. (1999). Pastoral counseling: The basics. Louisville, KY: Westminster John Knox.

Dykstra, R. C. (2001). Discoverìng a sermon: Personal pastoral preaching. St. Louis, MO: Chalice.

Dykstra, R. C., Cole, A. H., and Capps, D. (2007). Losers, loners, and rebels: The spiritual struggles of boys. Louisville, KY: Westminster John Knox.

Elkind, D. (1989). The hurried child: Growing up too fast too soon. Reading, MA.: Perseus.

Ennew, J. (1994). Time for children or time for adults. In J. Qvortrup, M. Bardy, G. Sgritta, and H. Wintersberger (Eds.), Childhood matters: Social theory, practice, and politics. Aldershot: Avebury. 
Erikson, E. H. (1950, 1963, Rev. Ed.). Childhood and society. New York, NY: W. W. Norton.

Erikson, E. H. (1964). Insight and responsibility: Lectures on the ethical implications of psychological insight. New York, NY: W. W. Norton.

Erikson, E. H. (1966). The ontogeny of ritualization in man. In R. M. Loewenstein et al. (Eds.), Psychoanalysis: A General Psychology. New York, NY: International Universities Press.

Erikson, E. H. (1970). Autobiographic notes on the identity crisis. Journal of American Academy of Arts and Sciences, 99/4, 730-759.

Erikson, E. H. (1977). Toys and reasons: Stages in the ritualization of experience. New York, NY: W. W. Norton.

Erikson, E. H. (1982). The life cycle completed: A review. New York, NY: W. W. Norton.

Erikson, E. H. and Erikson, J. M. (1998). The life cycle completed: Extended version with new chapters on the ninth stage of development. New York, NY: W. W. Norton.

Evans, R. I. (1967). Dialogue with Erik Erikson. New York, NY: Harper \& Row.

Friedman, L. J. (1999). Identity's architect: A biography of Erik H. Erikson. New York, NY: Scribner.

Gaillardetz, R. R. (2000). Transforming our days: Spirituality, community and liturgy in a technological culture. New York, NY: Crossroad.

Gill-Austern, B. (1995). Recovering hidden treasures for pastoral care. Pastoral Psychology, 43/4, 233-253. 
Goodnow, J. J. and Bowes, J. M. (1994). Men, women, and household work. Oxford: Oxford University Press.

Hammon, J. J. (2007). Becoming a pastor: Forming self and soul for ministry. Cleveland, OH: Pilgrim.

Homburger, E. (1937). Configurations in play: Clinical notes. Psychoanalytic Quarterly, 6, 139-212.

Jensen, D. H. (2005). Graced vulnerability: A theology of childhood. Cleveland, OH: Pilgrim.

Kelly-Byrne, D. (1989). A child's play life: An ethnographic study. New York, NY: Teacher's College Press.

Kohut, H. (1980). Forms and transformations of narcissism. In P. Ornstein (Ed.), The search for the self, vol.I (pp. 427-460). New York, NY: International Universities Press.

Koppel, M. S. (2003). A pastoral theological reflection on play in the ministry. Journal of pastoral theology, 13/1, 1-12.

Koppel, M. S. (2008). Open-hearted ministry: Play as key to pastoral leadership. Philadelphia, PA: Fortress.

Lester, A. D. (1985). Pastoral care with children in crisis. Philadelphia, PA: Westminster.

Medrich, E. A., Roizen, J., Rubin, V. and Buckley, S. (1982). The serious business of growing up: A study of children's lives outside of school. Berkeley, CA: University of California Press.

McClelland, D. C. (1961). The achieving society. New York, NY: Free Press. 
, B. J. (2003). Let the children come: Reimagining children from a Christian perspective. San Francisco, CA: Jossey-Bass.

, B. J. (2006). In the midst of chaos: Care of children as spiritual practice. San Francisco, CA: Jossey-Bass.

, B. J. (2007). The ‘clerical paradigm': A fallacy of misplaced concreteness?

International journal of practical theology, 11/2, 19-38

, B. J. (2008a). Practical theology and pedagogy: Reappraising theological know-how. In

D. Bass and C. Dykstra (Eds.), For life abundant: Practical theology in the education and formation of ministers (pp. 170-190). Grand Rapids, MI:

Eerdmans.

, B. J. (2008b). Children, chores, and vocation: A social and theological lacuna. In P. M.

Brennan and J. E. Coons (Eds.), The vocation of the child (pp. 295-323). Grand Rapids, MI: Eerdmans.

, B. J. (forthcoming 2008c). Work, play, and household chores: A Christian theological reflection on children and vocation. In M. Bunge (Ed.), Children, community, and faith formation: Perspectives from Judaism, Christianity, and Islam. Grand Rapids, MI: Eerdmans.

Mintz, S. (2004). Huck's raft: A history of American childhood. Cambridge, MA: Harvard University Press.

Rahner, K. (1971). Ideas for a theology of childhood. In Theological investigations, vol. 8 (pp. 33-50). London: Draton, Longman \& Todd.

Rodgers, D. (1985). Socializing middle-class children: Institutions, fables, and work values in nineteenth-century America. In R. R. Hiner and J. M. Hawes (Eds.), 
Growing up in America: Children in historical perspective (pp. 119-132).

Chicago, IL: University of Illinois Press.

Roy, P. (1961). Maternal employment and adolescent roles: Rural-urban differences. Marriage and family living, 23, 340-349.

Singer, R. (2004). Are we having fun yet? In P. B. Pufall and R. P. Unsworth (Eds.), Rethinking childhood (pp. 207-225). New Brunswick, NJ: Rutgers University Press, 2004.

Smith, P. K. (1995). Play, ethnology, and education: A personal view. In A. D. Pelligrini (Ed.), The future of play theory: A multidisciplinary inquiry into the contributions of Brian Sutton-Smith (pp. 3-22). New York, NY: State University of New York Press.

Stearns, P. N. (2003). Anxious parents: A history of modern childrearing in America. New York, NY: New York University Press.

Stephens, W. N. (1979). Our children should be working. Springfield, IL: Charles C. Thomas Publisher.

Sutton-Smith, B. (1997). The ambiguity of play. Cambridge, MA: Harvard University Press.

Walker, K. E. and Woods, M. (1976). Time use: A measure of household production of family goods and services. Washington, DC: Center for the Family of the American Home Economics Association.

Weiss, N. P. (1985). Mother, the invention of necessity: Dr. Benjamin Spock’s Baby and Child Care. In N. R. Hiner and J. M. Hawes (Eds.), Growing up in America: 
Children in historical perspective (pp. 282-303). Urbana, IL: University of Illinois Press.

Winnicott, D. W. (1941). The observation of infants in a set situation. International journal of psychoanalysis, 22, 229-249.

Winnicott, D. W. (1958). Symptom tolerance in pediatrics. In Collected papers: Through pediatrics to psychoanalysis (pp. 101-117). London: Tavistock Publications.

Winnicott, D. W. (1971). Playing and reality. London: Tavistock, 1971.

White, L. K. and Brinkerhoff, D. B. (1981). Children's work in the family: Its significance and meaning. Journal of marriage and the family, 43/4, 789-798.

Zelizer, V. A. (1994). Pricing the priceless child: The changing social value of children. Princeton, NJ: Princeton University Press. 